\title{
Back to the Countryside: Rural Development and the Spatial Patterns of Population Migration in Zhejiang, China
}

\author{
Weiming Tong ${ }^{1,2, *(\mathbb{D})}$ and Kevin Lo ${ }^{3}(\mathbb{D}$ \\ 1 College of Economics, Zhejiang University of Technology, Hangzhou 310023, China \\ 2 Department of the Built Environment, Eindhoven University of Technology, \\ 5600 MB Eindhoven, The Netherlands \\ 3 Department of Geography, Hong Kong Baptist University, Hong Kong, China; lokevin@hkbu.edu.hk \\ * Correspondence: tongweiming@zjut.edu.cn
}

check for updates

Citation: Tong, W.; Lo, K. Back to the Countryside: Rural Development and the Spatial Patterns of Population Migration in Zhejiang, China. Agriculture 2021, 11, 788. https:// doi.org/10.3390/agriculture11080788

Academic Editor:

Gioacchino Pappalardo

Received: 9 July 2021

Accepted: 16 August 2021

Published: 18 August 2021

Publisher's Note: MDPI stays neutral with regard to jurisdictional claims in published maps and institutional affiliations.

Copyright: (c) 2021 by the authors. Licensee MDPI, Basel, Switzerland. This article is an open access article distributed under the terms and conditions of the Creative Commons Attribution (CC BY) license (https:// creativecommons.org/licenses/by/ $4.0 /)$.

\begin{abstract}
This study examines how rural development in China shapes new trends in population migration. Using first-hand, village-level data from Zhejiang-an economically developed province in China-we investigated the patterns and influencing factors of population migration between rural and urban areas. We conceptualized three types of migration in rural areas: rural out-migration, rural in-migration, and rural return-migration. First-hand data were collected from 347 villages. The results show that although rural out-migration remains the dominant form of migration, rural inmigration and return-migration are also common, and the latter two are positively correlated. Further, we found evidence to support the conclusion that rural economic, social, and spatial development encourages rural in-migration and return-migration but does not have a significant impact on rural out-migration. Therefore, it is foreseeable that rural in-migration and return-migration will become increasingly common in China.
\end{abstract}

Keywords: rural development; population migration; rural studies; China

\section{Introduction}

The internal population migration in China is a highly active research area in rural geography. Rural China has three main forms of internal migration. The first is rural out-migration, or rural-urban migration, which is by far the dominant mode in China. After the reform in 1978, the relaxation of mobility control and new economic opportunities in coastal regions resulted in a massive flow of rural surplus labor to the cities, estimated to be around 290 million people [1,2]. This massive flow of migration is an important driver of urbanization and industrialization but also creates problems of rural depopulation and decline, especially in the poorer inland regions [3-6]. Second, a trend of return-migration has been emerging, with rural migrants moving back to the countryside and small towns. Return-migration can be triggered by both the lack of economic opportunities in urban areas because of economic downturns or the emergence of new opportunities in rural areas $[7,8]$. It was estimated that more than 7.4 million villagers returned to their hometowns in 2017. Third, rural in-migration, including rural-to-rural and urban-to-rural movements, is a relatively new and less studied phenomenon. According to the latest $1 \%$ population survey conducted in 2015, 32.35 million new rural residents migrated from town-level administrative units [9]. Similar to the phenomenon elsewhere, people migrate to rural areas for a variety of reasons, including better quality of life and the natural and socio-economic values of rural areas [10]. As such, population migration can be understood as the response of migrants to spatial differences in natural, political, economic, social and cultural factors based on individual characteristics and preferences. Thus, the spatial patterns of migration are not static but are constantly shifting in response to changes in the underlying factors. One particularly important factor in China is the significant but highly uneven progress of rural development, especially in economically developed coastal regions. One key 
driver of change in rural development is economic growth. In the past, the urban economy developed rapidly, and cities expanded under the opening-up policy, resulting in a strong "absorption" effect for the rural surplus labor force to migrate to the cities [11]. However, the recent economic development of rural areas, driven by both bottom-up initiatives and top-down government policies, has gradually reduced the urban-rural divide [12,13]. In addition to conventional industrial development, new economic opportunities such as rural tourism and e-commerce are creating jobs and may attract return migrants and rural in-migration, as well as reduce rural out-migration [14-16]. Furthermore, government policies such as the Beautiful Villages initiative have enhanced rural attractiveness by improving the infrastructure and environmental qualities of the countryside $[17,18]$. Existing studies have systematically researched and discussed the theory and model of population migration, which can be traced back to the migration theory proposed by Levinstein in the 1980s. There are multiple theories that explain the macroscopic laws of population migration, including Lewis's dual economic structure theory, the Ranis-Feijinghan theory, Hebrel's thrust-pull theory, Todaro's expected income theory, Gefford's gravity model, and He Zelinski's theory of mobility rate transition. Furthermore, the human capital theory, expected income theory, and behavior theory of population migration explains population migration from a microscopic perspective, whereas the social network and cumulative causation theories of population migration operate from a mesoscopic perspective [19-23]. Moreover, research has focused on population migration mainly in terms of the relationship between population migration and urbanization; spatial characteristics of population migration; types, causes, and influencing factors of population migration; and policy research on population migration [24-27]. With a unique household registration system (hukou), migration control, and rural-urban development policies, population migration in China is different from the general pattern around the world. Domestic research on population migration is mainly carried out from the following four perspectives. First, regarding rural migrants, studies have examined the motivations, willingness, and influencing factors of migration, such as age, income, educational attainment, hukou, and membership in the Chinese Communist Party [28-31]. Second, studies from the perspective of migration processes focus on identifying and explaining the temporal and spatial patterns of rural migration [32-35]. Third, urban studies tend to focus on the impact of rural-to-urban migration on urban development and its challenges, such as housing, social exclusion, and integration [36-39]. Fourth, a number of studies exist from the perspective of rural studies, with a strong focus on examining the impact of the outflow of rural residents, such as rural hollowing, rural poverty, and social issues such as inequality, neglected children and elderly people [4,40-43]. Of particular relevance to this study, research on the factors influencing population migration in China can be classified into two major groups. One group of micro-level studies focuses on the social and economic characteristics of individuals, including gender, age, education level, employment, family structure, and other socio-economic attributes. The second group of macro-level studies examines regional factors, such as differences in economic development level, employment opportunities, and income levels between regions, as the main factors affecting population migration. However, most studies focus on the influence of urban development factors on population migration, whereas relatively few studies have focused on the impacts of rural development factors on population migration. Furthermore, most studies focus on rural out-migration, whereas rural in-migration and return-migration are relatively neglected. Consequently, there is a lack of understanding of the changes in population migration in the ongoing process of rural development in China. This study aims to identify the latest spatial patterns of internal population migration and to analyze the key factors influencing population migration using empirical village-level data. Empirical data are drawn from a survey conducted in Zhejiang Province in eastern coastal China, where both highly developed and underdeveloped villages exist. This can be considered a microcosm of China's rural development. The results can enhance our understanding of how rural development shapes the complex patterns of population migration. The rest of this paper 
is organized as follows. Section 2 presents the materials and methods, Section 3 reports the results, Section 4 presents the discussion, and Section 5 presents the conclusions.

\section{Materials and Methods}

\subsection{Data Collection}

The data in this paper were mainly taken from a survey and were complemented with the data from the Zhejiang Statistical Yearbook (2019) and the China County and City Statistical Yearbook (2017 township volume). First-hand data were collected from 347 villages in Zhejiang Province. The rural areas of Zhejiang Province had a total of 693 towns, 269 townships, and 24,711 villages. Therefore, the sample survey villages account for $1.4 \%$ of the entire province's villages. The 347 randomly selected villages included 52 villages in Hangzhou, 31 in Ningbo, 57 in Wenzhou, 46 in Shaoxing, 12 in Huzhou, 25 in Jiaxing, 34 in Jinhua, 20 in Quzhou, 47 in Taizhou, 21 in Lishui, and 2 in Zhoushan.

Fieldwork was conducted from December 2019 to January 2020. We recruited students as investigators from Zhejiang University of Technology, where more than 80 percent students are from Zhejiang Province. The recruited students were all rural residents aged over 18 and each student investigator was responsible for completing a questionnaire and an interview survey at one village, which was typically his or her home village. This strategy was important because, on one hand, the students were familiar with the surveyed village and understood the local situation. On the other hand, the rural residents were familiar with the students, so they were more willing to have open and in-depth discussions. To ensure the reliability of the data collection process, all investigators received adequate training before conducting fieldwork. The questionnaire consisted of three parts. First, the basic situation of the village was discussed, including the location and resource characteristics, the population profile, and the levels of rural industry development, housing, environment, infrastructure, and rural development. Second, the degree and frequency of rural population migration, including rural out-migration, rural in-migration, and return-migration, were established. Third, the rural development situation, including the development stage and the current rural social, economic, and spatial transformation situation, was addressed.

\subsection{Case Study Area}

Zhejiang Province was used as a case study to reveal the impact and mechanism of rural development on population migration. Zhejiang was a suitable site for this study because the province has always been at the forefront of rural development in China. Zhejiang Province is located on the southeast coast of China (Figure 1). As the economic core area of the Yangtze River Delta region, Zhejiang achieved a high level of rural industrialization by as early as 1998, when there were 1,026,200 township enterprises with a total output value of 1010.876 billion RMB. The township enterprises of Zhejiang are well developed. The proportion of township industry in the total output value of rural areas increased remarkably from $21.99 \%$ in 1978 to $93.18 \%$ in 2001 . Zhejiang was the first province to eradicate rural absolute poverty in China in 2007. In 2018, the per capita disposable income of permanent rural residents in Zhejiang was 27,302 RMB, ranking first among all provinces and regions in China for 34 consecutive years. Zhejiang Province has a high degree of intensive rural land use, with $55.4 \%$ of contracted farmland transferred. The urbanization level in Zhejiang Province was 70.0\% in 2019, which was significantly higher than the national average level of $60.6 \%$.

\subsection{Models and Variable Descriptions}

To explore the influencing factors of rural development on population migration in rural areas, we developed an index system for variables which influenced population migration from the perspective of rural economic, social, and spatial transformation (Table 1). The model variables included basic rural attributes; the rural degree of economic, social, and spatial development; and population migration factors. The basic attributes of rural 
areas included the village types and the major transformation stages of rural areas. The village types included agriculture-oriented villages, eco-tourism villages, large-scale industrial villages, and small-scale industrial villages. The major stages of rural transformation included the stages of Urban-Rural Integration from 2003 to 2005, New Rural Construction from 2005 to 2017, and Rural Revitalization from 2017 to the present. The factors of rural economic development included the overall development degree of the rural economy, development status of agriculture, development status of industry, and development status of the service industry. The factors of rural social development included the overall development degree of the rural society, infrastructure conditions, public service level, education level, medical treatment level, social security level, and environmental management level. The factors of rural spatial development included the overall development degree of rural space, reasonable spatial distribution degree of villages, degree of agricultural land mechanization, and ecological conditions. Further, the factors of population migration included the degrees of rural out-migration, rural in-migration, and rural return-migration.

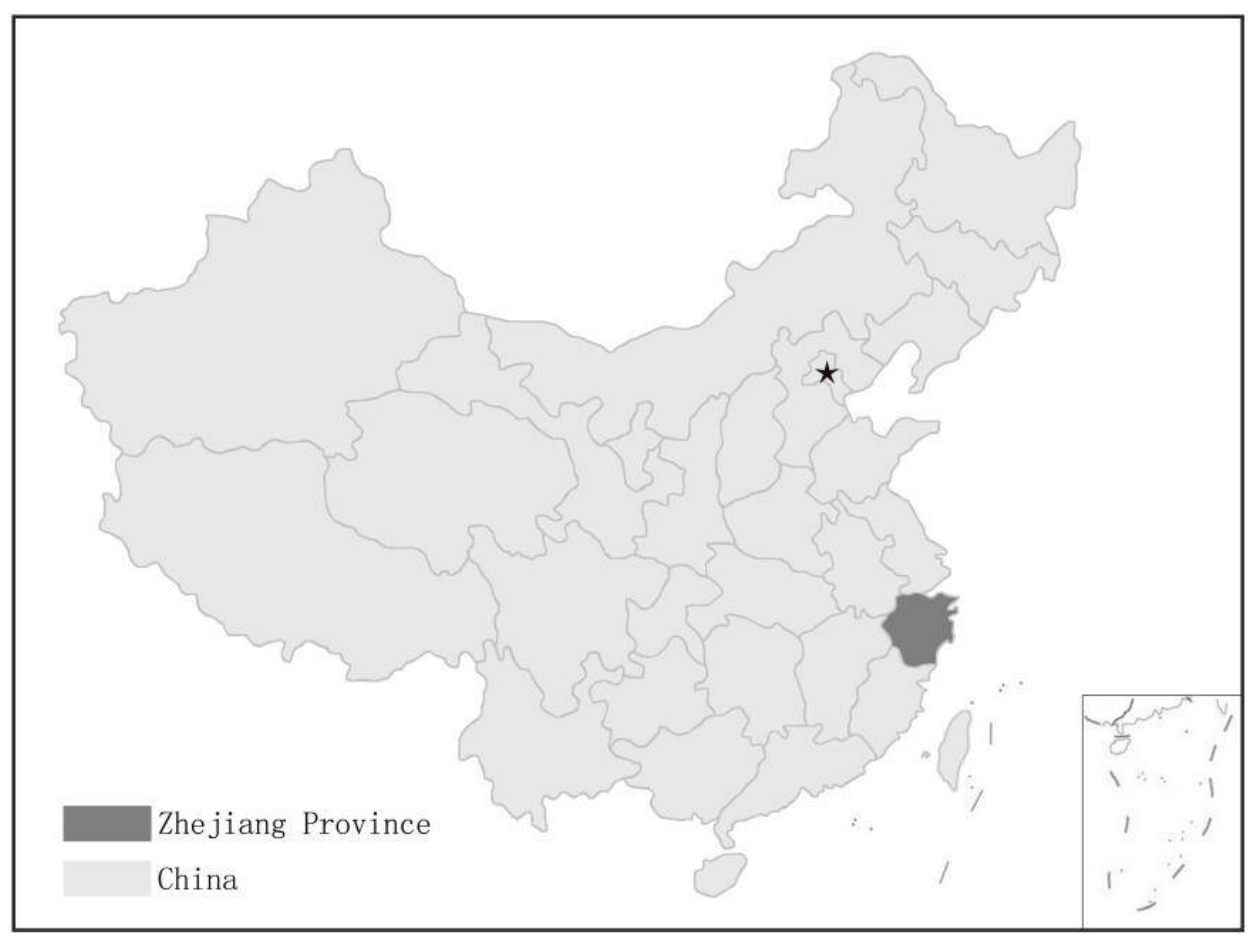

Figure 1. The location of Zhejiang Province in China.

The degrees of population migration and social, economic, and spatial development were continuous variables that were suitable for multiple linear regression models. Therefore, multiple linear regression was adopted in this study to establish the predictors of population migration in rural areas. This paper has three hypotheses. (1) The factors of rural, social, economic, and spatial development and of population migration affect rural out-migration. (2) The factors of rural social, economic, and spatial development, and factors of population migration, affect rural in-migration. (3) The factors of rural social, economic, and spatial development and those of population migration affect rural return-migration. 
Table 1. Variable descriptions.

\begin{tabular}{|c|c|c|}
\hline Variable Category & Variable Name & Variable Coding \\
\hline \multicolumn{3}{|l|}{ Basic rural attributes } \\
\hline \multicolumn{3}{|l|}{ Village type } \\
\hline & Eco-tourism villages & Dummy coding \\
\hline & Large-scale industrial villages & Dummy coding \\
\hline & Small-scale industrial village & Dummy coding \\
\hline \multirow{4}{*}{$\begin{array}{l}\text { Major stage of } \\
\text { rural development }\end{array}$} & New Rural Construction and & \\
\hline & Beautiful Rural Construction & Dummy coding \\
\hline & Rural Revitalization & Dummy coding \\
\hline & Urban-Rural Integration & Dummy coding \\
\hline \multicolumn{3}{|l|}{ Degree of rural development } \\
\hline \multirow[t]{4}{*}{ Rural economic development } & $\begin{array}{c}\text { Overall transformation and } \\
\text { development degree of } \\
\text { rural economy }\end{array}$ & Continuous variables \\
\hline & Development status of agriculture & Continuous variables \\
\hline & Development status of industry & Continuous variables \\
\hline & $\begin{array}{l}\text { Development status of } \\
\text { service industry }\end{array}$ & Continuous variables \\
\hline \multirow[t]{7}{*}{ Rural social development } & $\begin{array}{l}\text { Overall development degree of } \\
\text { rural society }\end{array}$ & Continuous variables \\
\hline & Infrastructure conditions & Continuous variables \\
\hline & Public service level & Continuous variables \\
\hline & Education level & Continuous variables \\
\hline & Medical treatment level & Continuous variables \\
\hline & Social security level & Continuous variables \\
\hline & Environmental management level & Continuous variables \\
\hline \multirow[t]{4}{*}{ Rural spatial development } & $\begin{array}{c}\text { Overall transformation and } \\
\text { development degree of } \\
\text { rural space }\end{array}$ & Continuous variables \\
\hline & $\begin{array}{l}\text { Reasonable spatial distribution } \\
\text { degree of villages }\end{array}$ & Continuous variables \\
\hline & $\begin{array}{c}\text { Degree of agricultural land } \\
\text { mechanization }\end{array}$ & Continuous variables \\
\hline & Ecological conditions & Continuous variables \\
\hline \multicolumn{3}{|l|}{$\begin{array}{c}\text { Factors of } \\
\text { population migration }\end{array}$} \\
\hline & Rural out-migration & Continuous variables \\
\hline & Rural in-migration & Continuous variables \\
\hline & Rural return-migration & Continuous variables \\
\hline
\end{tabular}

\section{Results}

\subsection{Characteristics of Rural Development}

The survey results show that $54.5 \%$ of villages participated in the New Rural Construction and Beautiful Rural Construction policy, $41.2 \%$ of the villages participated in Rural Revitalization, and only $4.3 \%$ participated in Urban-Rural Integration. These results shows that state-led rural development policies have been implemented in all villages.

Rural enterprises play an important role in driving the transformation of rural industries. Zhejiang has a well-developed rural enterprise sector. Tuanyan Village, for example, is a village dominated by industrial development. A villager in the survey reported that "There are 73 village enterprises in our village, enterprises are mainly concentrated in light industry, such as flashlight accessory and daily necessities". However, even in Zhejiang, not all villages developed their own industries. According to the survey, the proportion of large-scale industrial villages was $23.6 \%$, that of small-scale industrial villages was $21.3 \%$, that of eco-tourism villages was $12.1 \%$, and that of agriculture-oriented villages was $42.9 \%$. Kangyuan Village, for example is a typical traditional agricultural village, which is dominated by the farmer-owned industrial land and has a low degree of agricultural industrialization with problems of a limited resource base and lack of industrial support. 
In the investigation, a villager reported that "Kangyuan village has insufficient resources, only including cultivated land resources and forest resources. The cultivated land is mainly mountainous, and the forest resources are mainly bamboo and fresh bamboo shoots. With the increase of labor cost, it is difficult to make profits by cutting down bamboo and selling and drawing plants. In the early stage, there were pressing plate factory, quarry and other large pollution-type factories in the village. Later, due to the beautiful rural construction of the village, the development concept that green water and green mountains were gold and silver was implemented. The pollution-type factories were all dismantled, so there is no factory in the village".

The survey results show that $40.7 \%$ of the villages had a high degree of economic development, whereas $40.3 \%$ of villages had economies with lower degrees of development, dominated by traditional agricultural villages in Zhejiang Province (Table 2). The results also show that $51.0 \%$ of villages had high degrees of social development and $57.3 \%$ of villages had high degrees of spatial transformation. These results are consistent with the actual situation of the rural social and spatial transformation in Zhejiang Province. Through the construction of beautiful villages in 2010, the government improved rural infrastructure support and the ecological environment. Villagers in Anxi Village indicated in the survey that "Our rural environment is good, the rural garbage is sorted and recycled, and the infrastructure such as the water and electricity pipeline network is also relatively complete (Figure 2)".

Table 2. Development levels of the surveyed villages.

\begin{tabular}{ccccccc}
\hline \multirow{2}{*}{ Levels } & \multicolumn{2}{c}{ Economic Development } & \multicolumn{2}{c}{ Social Development } & \multicolumn{2}{c}{ Spatial Development } \\
\cline { 2 - 7 } & Frequency & $\%$ & Frequency & $\%$ & Frequency & $\%$ \\
\hline Very low & 16 & 4.6 & 5 & 1.4 & 8 & 2.3 \\
Low & 50 & 14.4 & 29 & 8.4 & 34 & 9.8 \\
Slightly low & 74 & 21.3 & 64 & 18.4 & 47 & 13.5 \\
Moderate & 66 & 19.0 & 72 & 20.7 & 59 & 17.0 \\
Slightly high & 80 & 23.1 & 103 & 29.7 & 100 & 28.8 \\
High & 55 & 15.9 & 68 & 19.6 & 90 & 25.9 \\
Very high & 6 & 1.7 & 6 & 1.7 & 9 & 2.6 \\
Total & 347 & 100.0 & 347 & 100.0 & 347 & 100.0 \\
\hline
\end{tabular}

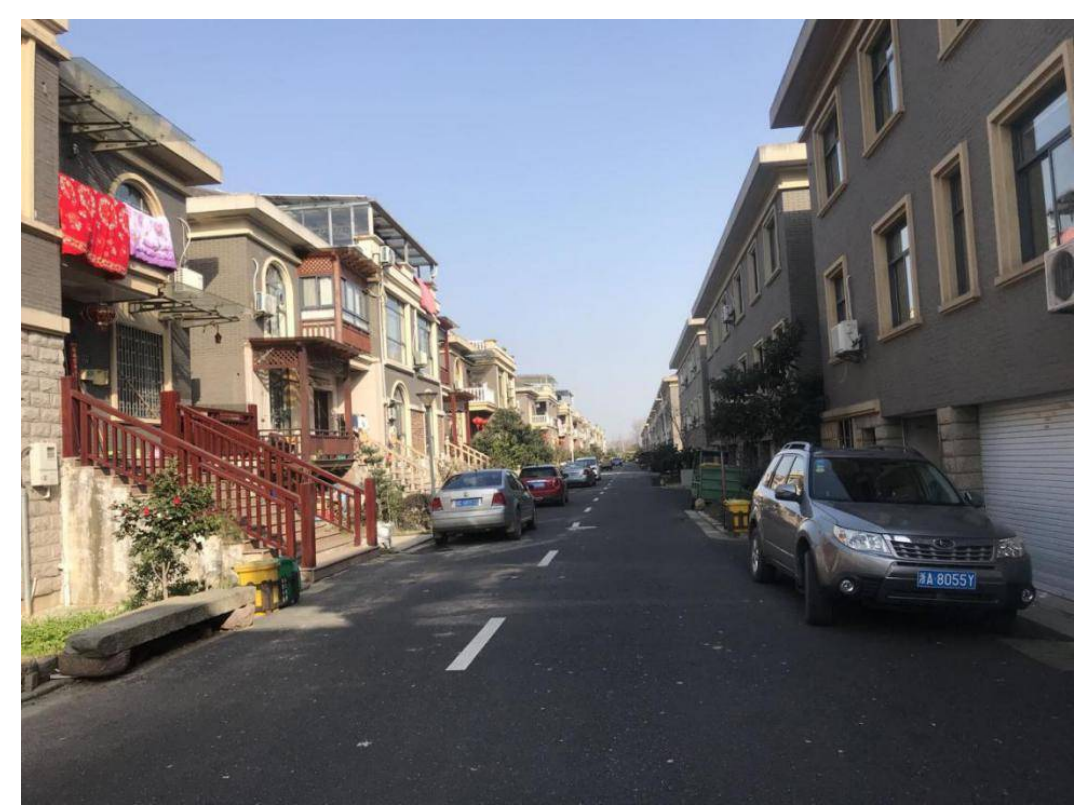

Figure 2. Photograph of Anxi Village, Zhejiang Province. 


\subsection{Characteristics of Population Migration in Rural Areas}

The survey data show that the main feature of population migration in rural areas of Zhejiang Province is the high degree of rural out-migration, with a proportion of $51.0 \%$ in the slightly high, high, and very high categories combined. Less common, but far from infrequent, is rural in-migration, with $18.7 \%$ of the surveyed villages reporting slightly high, high, or very high degrees. Rural return-migration is the least common, with $13.5 \%$ of the surveyed villages reporting the phenomenon as slightly high, high, or very high (Table 3 ).

Table 3. Degree of population migration in the village area.

\begin{tabular}{ccccccc}
\hline \multirow{2}{*}{ Degree } & \multicolumn{2}{c}{ Rural Out-Migration } & \multicolumn{2}{c}{ Rural In-Migration } & \multicolumn{2}{c}{ Rural Return-Migration } \\
\cline { 2 - 7 } & Frequency & $\mathbf{\%}$ & Frequency & $\%$ & Frequency & $\%$ \\
\hline Very low & 9 & 2.6 & 61 & 17.6 & 36 & 10.4 \\
Low & 37 & 10.7 & 102 & 29.4 & 104 & 30 \\
Slightly low & 44 & 12.7 & 53 & 15.3 & 78 & 22.5 \\
Moderate & 80 & 23.1 & 66 & 19 & 82 & 23.6 \\
Slightly high & 82 & 23.6 & 38 & 11 & 25 & 7.2 \\
High & 75 & 21.6 & 22 & 6.3 & 22 & 6.3 \\
Very high & 20 & 5.8 & 5 & 1.4 & 0 & 0 \\
Total & 347 & 100 & 347 & 100 & 347 & 100 \\
\hline
\end{tabular}

\subsection{Influencing Factors of Rural Development on Rural Out-Migration}

Based on the correlation analysis of rural out-migration and rural development factors, this type of migration is not related to the basic attributes of rural areas, the degree of rural economic, social, and spatial transformation, or the factors of population migration. Therefore, the hypothesis that "factors of rural development and factors of population migration influence population migration" is not supported.

\subsection{Influencing Factors of Rural Development on Rural In-Migration}

The degree of rural in-migration is related to rural development factors; consequently, a regression model is established. Model 1 explores the impacts of basic rural attributes and the degree of rural development on rural in-migration. The results show that large-scale industrial villages and small-scale industrial villages attract other urban and rural residents to migrate to rural areas. Model 2 explores the impacts of basic rural attributes, the degree of rural development, and factors of population migration on rural in-migration (Table 4). The results show that the basic attributes of rural areas, the degree of development, and some elements of population migration are important factors affecting the in-migration of other urban and rural residents.

The basic attributes of rural areas affect rural in-migration. Compared with traditional agricultural villages, large-scale and small-scale industrial villages are much more attractive to other urban and rural residents. The results are consistent with the finding that industrial development provides a large number of jobs, thereby promoting rural in-migration.

The degree of rural economic development positively affects rural in-migration. The results show that rural economic development can attract other urban and rural residents to move in, and a higher degree of economic development is associated with a higher degree of in-migration. This is because rural industrial enterprises are typically labor-intensive, which can provide many employment opportunities. For example, the respondent in Ertangxin Village in Ningbo stated that "there are more than 70 township enterprises in Ertangxin Village, mainly producing plastics and hardware products". With the continuous expansion of the industrial park in the village, many other urban and rural residents have been attracted to work and live in the village. The population of other urban and rural residents accounts for about one-third of the total village population". 
Table 4. Factors affecting rural in-migration.

\begin{tabular}{ccc}
\hline Varables & Model 1 & Model 2 \\
\cline { 2 - 3 } & $\boldsymbol{\beta}$ & $\boldsymbol{\beta}$ \\
\hline Basic rural attributes & & \\
Large-scale industrial villages & $0.12^{*}$ & $0.10^{*}$ \\
Small-scale industrial village & $0.11^{*}$ & \\
The stage of rural revitalization & $-0.25^{*}$ & $0.26^{* * *}$ \\
Degree of rural development & & $0.15^{*}$ \\
Overall development degree of rural economy & $0.32^{* * *}$ & $-0.13^{*}$ \\
Development status of industry & $0.14^{*}$ & $-0.14^{*}$ \\
Overall development degree of rural society & & $-0.14^{*}$ \\
Social security level & $-0.15^{*}$ & $0.30^{* * *}$ \\
Ecological environment management level & $-0.17^{* *}$ & 0.3 \\
Factors of population migration & & $7.9(p \leq 0.000)$ \\
The degree of rural return-migration & & \\
Adjusted $\mathrm{R}^{2}$ & 0.23 & \\
$\mathrm{~F}$ & $6.23(p \leq 0.000)$ &
\end{tabular}

The degree of rural spatial development negatively affects rural in-migration. The results show that a better ecological environment in rural areas is associated with lower rural in-migration. This may be because the development of polluting industries is highly restricted in areas with better rural ecological governance. In the process of rural environmental governance, Zhejiang Province has shut down some of the more polluting township enterprises. These villages with better environments are mainly based on eco-tourism and traditional agricultural development. The limited scale of industrial development in these rural areas restricts in-migration. For example, the population structure of Qingfeng Village in Zhejiang Province is dominated by local villagers. As no industrial enterprises exist in Qingfeng Village, the village mainly focuses on the development of traditional agriculture and tertiary industries. The rural social security level, even if relatively low, can also attract rural populations to move in. Although the development of urban and rural social security systems in Zhejiang Province is at the forefront of China's industry, significant gaps exist between urban and rural areas in terms of project coverage, security level, management systems, and treatment level [37]. In the case of low social security levels in rural areas, other rural and urban villagers still move to those rural areas, indicating that high-welfare rural and social security is not the main factor affecting their migration to rural areas.

The results show that rural return-migration, but not rural out-migration, is statistically related to rural in-migration. A higher degree of return-migration is associated with a higher degree of rural in-migration. This is because a high degree of return-migration implies a high level of rural attractiveness, thus also attracting rural in-migration.

Model 1 has an adjusted $R^{2}$ of 0.23 . This means that $23 \%$ of the variance in rural inmigration scores can be explained by basic rural attributes and degree of rural development. Model 2 has an adjusted $R^{2}$ of 0.3 , which indicates that $30 \%$ of the variance in rural inmigration scores can be explained by basic rural attributes, the degree of rural development and factors of population migration. Furthermore, Model 2 has more explanatory power than Model 1. This finding underlines the importance of a strong degree of return-migration as an instrument to increase rural in-migration. The variables' values of VIF used in Models 1 and 2 are all below 5 , which indicates that there is no multicollinearity.

\subsection{Influencing Factors of Rural Development on Rural Return-Migration}

The degree of rural return-migration is correlated with the rural development factors, and a regression model is established. Model 3 explores the impact of rural basic attributes and rural development on rural return-migration, whereas Model 4 includes population migration factors (Table 5). The results show that some factors of rural development and 
population migration are important in affecting return-migration. However, the basic attributes of rural areas have no significant effect on return-migration.

Table 5. Factors affecting rural return-migration.

\begin{tabular}{ccc}
\hline Varables & Model 3 & Model 4 \\
\cline { 2 - 3 } & $\boldsymbol{\beta}$ & $\boldsymbol{\beta}$ \\
\hline Degree of rural development & & \\
overall development degree of rural economy & $0.21^{*}$ & \\
Infrastructure conditions & $-0.19^{*}$ & $0.17^{*}$ \\
Education level & $0.19^{*}$ & $0.24^{*}$ \\
Social security level & $-0.15^{*}$ & $0.14^{*}$ \\
Reasonable spatial distribution & $0.27^{* *}$ & $-0.12^{*}$ \\
Ecological environment conditions & & $0.33^{* * *}$ \\
Factors of population migration & & 0.29 \\
Degree of rural out-migration & & $6.03, p \leq 0.000$ \\
Degree of rural in-migration & &
\end{tabular}

The results show that rural economic development positively affects return-migration. If the degree of rural economic development is high, the village can provide sufficient jobs, thereby attracting villagers to return. In Hanjia Village of Zhejiang Province for example, a respondent revealed that "the degree of villagers' backflow is relatively high in our village, because our village has more than thirty factories, which are mainly engaged in processing and manufacturing, producing and supplying spare parts. Furthermore, the development of the tertiary industry is mainly based on the development of rural tourism combining farm tourism, sales, catering and leisure".

Rural social development also positively affects return-migration. In particular, with a higher education level in the village, more villagers are attracted to return. Furthermore, a better rural environment is associated with a higher degree of return-migration. Through various government policies, rural living environments and ecological environments have been improved through projects such as road hardening, street lighting, river purification, pole and wire sequencing, wall beautification, sanitation, and environmental greening. The improvement of the rural environment is shown to be conducive to attracting the rural population to return. Zhejiang's current level of rural social security and infrastructure development, although not high, can also attract villagers to return. These results are consistent with those of previous studies. The level of infrastructure is negatively correlated with the amount of rural population reflux, and the effect of infrastructure level on population migration is relatively weak.

The spatial development of rural areas affects rural return-migration. A more reasonable village layout is associated with a higher degree of population return. The comments from respondents reveal that, compared with the layouts of cities, rural areas have the characteristics of dispersed layouts and low-density building environments, which are important factors in attracting the rural residents to return.

Some migration factors affect return-migration. The degree of rural in-migration is positively correlated with return-migration and negatively correlated with out-migration. In villages with higher degrees of out-migration, the degrees of return-migration are lower. However, in villages with higher degrees of rural in-migration, the degrees of return-migration are higher.

Model 3 has an adjusted $\mathrm{R}^{2}$ of 0.21 . This means that $21 \%$ of the variance in rural return-migration scores can be explained by the degree of rural development. Model 4 has an adjusted $R^{2}$ of 0.29 , which indicates that $29 \%$ of the variance in rural return-migration scores can be explained by the degree of rural development and factors of population migration. Model 4 has more explanatory power than Model 3. This finding underlines 
the importance of a strong degree of out-migration and in-migration as an instrument to increase the rural return-migration. The variables' values of VIF used in the Models 3 and 4 are all below 5 , which indicates that there is no multicollinearity.

\section{Discussion}

This section discusses the leading mechanisms of rural development affecting population migration in terms of economic factors, resource base, land circulation, and policies. The economic factors, resource base, land circulation, and policies are also key factors which affect rural economic, social, and spatial development.

\subsection{Economic Factors}

Economic factors are important factors leading to population migration. At present, significant differences remain between urban and rural economic development in China. The push-pull effect formed by the differences in economic development levels between urban and rural areas also leads to large-scale rural-urban population migration. Since the implementation of China's reform and opening-up policies, the development of township enterprises in Zhejiang Province has led to considerable demand for labor, thereby attracting many residents of other urban and rural areas to move to rural areas. This is in line with the results that the degree of rural economic development affects rural in-migration and return-migration. The population in these rural areas has become a large driving force in the development and transformation of the rural economy, and the differences between urban and rural economic development have gradually decreased. Thus, the transformation of the rural economy will form population reflux pull and make these areas more attractive for other urban and rural residents, gradually promoting population migration from a benign circulation system in the process of the evolution of an urban-rural economy system development.

\subsection{Resource Base}

The resource base provides the foundation for rural economic, social and economic development and therefore is an important supporting factor of population migration. The total land area of Zhejiang Province is 105,500 square kilometers, of which the cultivated land area is 1977.04 thousand hectares. Zhejiang is a high-yielding comprehensive agricultural area in China, which produces tea, silk, aquatic products, citrus, and bamboo products. Mineral resources in Zhejiang Province are mainly nonmetallic minerals. The reserves of stone coal, alum stone, pyrophyllite, tuff for cement, and tuff for construction rank first in China, and the fluorite reserves rank second in China. Seven mountainous areas, one water body area, and two plain areas characterize the general topography of Zhejiang. Zhejiang Province has more than 30 lakes with a volume of more than 1 million cubic meters, such as West Lake and Dongqian Lake. The coastline (including islands) is more than $6400 \mathrm{~km}$ long; therefore, the cultural tourism resources are very abundant.

\subsection{Land Circulation}

In China, all land is publicly owned; no private land ownership is allowed because of the socialist system of government. The public land ownership system takes the form of state ownership in urban areas and collective ownership in rural areas. "Collective" in this context refers to collective economic organizations of farmers, such as agricultural production cooperatives, which own the land on behalf of the farmers.

After the implementation of reform and opening-up policies in 1978, with the rapid development of China's urbanization process, millions of villagers moved to the cities, which led to critical problems such as the hollowing out of the countryside. Since the 1980s, China adopted a household contract system. Under this system, farmers are given the right to use the land to which they have been contracted to work, rather than outright ownership. Usage rights on agricultural land (contractual management rights) last for 30 years. However, the household contract system often divides farmland into many 
small pieces, which limits mechanization and large-scale agricultural production. To address the problems of rural land fragmentation and hollowing out, China's government encouraged the vigorous development of land circulation and moderate-scale operations in 2014. Land circulation refers to the transfer of land use rights to other farmers or economic organizations by farmers with contracted land management rights. That is, to retain the right to contract and transfer the right to use. The Zhejiang provincial government guided many different organizations and individuals to participate in land circulation so that land contracts and management rights can be transferred to family farms and agricultural cooperative organizations run by villagers to achieve the large-scale operation of rural land. The provincial government also encouraged land circulation in industrial and commercial enterprises, which would invest in profitable agriculture and participate in large-scale land management and the base construction and development of agricultural products. The conversion of agricultural land and rural construction land changes the spatial development of rural areas and promotes the building of factories, urban housing, and infrastructure [44]. Moreover, the industrial development provides a large number of jobs, thereby promoting rural in-migration, which is in line with the results that, when compared with traditional agricultural villages, large-scale and small-scale industrial villages are much more attractive to other urban and rural residents.

Land circulation induced population migration and profoundly changed the pattern of population migration, promoting the two-way migration of urban and rural populations to a certain extent. Land circulation changed the rural agricultural dispersion management pattern; accelerated the development of rural space transformation; significantly improved the agricultural scale, organization, and industrialization levels; and prompted the employment of rural residents from agriculture to nonagricultural industries. Hence, a large amount of rural surplus labor force was produced to drive rural-urban population migration. In addition, the corporate production and $R \& D$ of agricultural and sideline products provided jobs for the surplus labor force, whichattracted other urban and rural residents to move to rural areas, as well as some villagers to return.

\subsection{Rural Development Policies}

Policies are important factors that promote or inhibit population migration, including household registration policies and rural development policies. After the reform and opening-up in 1978, the implementation of land policy reform (i.e., the household contract responsibility to release a large amount of surplus rural labor) has led to the promotion of rural-urban population migration. However, the urban and rural household registration system and the dual social system have inhibited rural-urban migration. In 1984, China launched a policy of encouraging the migration of rural surplus labor into towns, which led to large-scale rural-urban population migration. After the 1990s, to accelerate the process of urbanization in China, the household registration policy of the rural population settled in cities and towns was relaxed. Members of rural populations who have lived and been employed in small towns, and meet certain conditions, can apply for urban hukou (registered permanent residence). Policies of temporary population registration in urban areas have also been adopted to promote rural-urban population migration.

Since 2003, Zhejiang Province has adopted rural development policies, such as the Thousand Villages Demonstration, Ten Thousand Villages Renovation project in 2003, the Beautiful Village policy in 2010, the Characteristic Towns policy in 2016, and Rural Revitalization in 2018. Under the policies of rural development, enterprises are driving the transformation of rural industries, and the government is driving the transformation of rural facilities and the ecological environment. This promotes the spatial development of rural areas to some extents. Therefore, the regional functions of rural areas in Zhejiang Province are constantly evolving and changing, and the rural socio-economics and regional spatial structure have undergone a dramatic reconstruction and transformation. Importantly, the policies of rural transformation development have effectively promoted the reflow and agglomeration of populations in rural areas. A new trend in the differentiation 
and migration of populations with urban and rural populations moving to rural areas and surrounding small towns, has emerged.

In 2018, the Chinese government highlighted that talent is the key to rural revitalization and developed pilot areas for talented people to return to their hometowns to start undertakings. China has 341 pilot areas, and seven counties and cities in Zhejiang Province have become national pilot areas, namely, Tonglu County, Qingyuan County, Yunhe County, Longquan City, Songyang County, Liandu District, and Sui chang county. National pilot programs for returning home and starting businesses and the development of rural businesses such as Alibaba's rural Taobao and agricultural production have actively promoted rural residents returning home and starting businesses.

\section{Conclusions}

This study contributes to the understanding of the profound impacts of rural development on the characteristics, direction, and patterns of internal population migration [45-47]. In particular, this paper explores the influence of three aspects of rural development (economic, social, and spatial) on three types of population migration (rural in-migration, rural out-migration, and rural return-migration). Based on a case study in Zhejiang, China, this study provides new first-hand evidence showing that the current rural population migration of Zhejiang is still dominated by rural out-migration, but rural in-migration and return-migration are not uncommon. Villages with advanced industrial development can provide more job opportunities and attract migrants and returnees. Thus, a higher degree of rural economic development is associated with more significant rural in-migration and return-migration. Rural social and spatial development, such as improving education levels, environmental conditions, and the sensibility of village and town layouts, positively affects return-migration. Rural in-migration and return-migration are positively related to each other, whereas rural out-migration is negatively correlated with return-migration.

China has regarded rural-urban migration as an important approach for promoting the urbanization process [48]. However, in response to the rural revitalization strategy, the population factor is the main target for tapping the potential of agriculture and rural areas and promoting rural development. Focusing on population migration to rural areas and rural population reflux would be suitable for prospective theoretical research and policy significance. These results are of particular relevance for policymakers who aim to increase rural in-migration and rural return-migration, in order for them to realize China's rural revitalization and reduce the gap between urban and rural areas. The results shed light on the rural economic, social, and spatial characteristics that policymakers could steer regarding rural population migration. First, policymakers should outline a policy to stimulate rural economy to offer more job opportunities to attract people to the rural areas, as the level of rural economy was found to have a positive effect on in-migration and rural return-migration. The rural economy could be stimulated by further promoting land circulation to support the land use of new industries in rural areas. Based on the local resources, rural economic development could also be achieved by extending the industrial chains of rural secondary industry, as well as developing leisure agriculture and rural tourism to enhance the integration of rural primary, secondary, and tertiary industries. Second, the level of rural social and spatial development was found to directly increase the likelihood of rural in-migration and return-migration. Therefore, policymakers are recommended to improve education levels, environmental conditions, and village and town layouts. In particular, for rural education, the government should achieve equal opportunities for education in urban and rural areas and arrange special financial funds to strengthen education and training for rural residents to attract rural returnmigration. Finally, under the background of China's rural revitalization development strategy, policymakers should plan for different types of pilots to attract enterprises to settle in the rural areas.

As Zhejiang can be considered a microcosm of rural development in China, its experience has implications at the national level. In particular, it is foreseeable that rural 
in-migration and return-migration will become increasingly common in China and may even reverse the trend of rural depopulation prevalent now. However, the results are based on a relatively small sample of respondents from specific rural areas in Zhejiang Province. We should therefore exercise reservation when generalizing the results. Further studies are needed to explore the interactions between different types of rural migration and rural development to reveal the relationship more comprehensively. More research is also needed to examine the socio-economic, environmental, and health impact of the population influx into rural areas and to develop the right policy responses and governance mechanisms that can address the new challenges.

Author Contributions: Conceptualization, W.T. and K.L.; methodology, W.T.; software, W.T.; validation, W.T. and K.L.; formal analysis, W.T.; investigation, W.T.; resources, W.T. and K.L.; data curation, W.T.; writing—original draft preparation, W.T. and K.L.; writing—review and editing, W.T. and K.L.; visualization, W.T.; supervision, K.L.; project administration, W.T.; funding acquisition, W.T. Both authors have read and agreed to the published version of the manuscript.

Funding: This research was funded by the National Natural Science Foundation of China, grant number 41901202, 42071159; The Pre-research Fund of Social Science Project of Zhejiang University of Technology, grant number SKY-ZX-20180236; National Social Major Science Foundation of China, grant number 18ZDA045 and China Scholarship Council, grant number 201404910592. The APC was funded by the National Natural Science Foundation of China.

Institutional Review Board Statement: Not applicable.

Informed Consent Statement: Not applicable.

Data Availability Statement: Not applicable.

Acknowledgments: We are grateful to three anonymous reviewers' comments and suggestions.

Conflicts of Interest: The authors declare no conflict of interest.

\section{References}

1. Chan, K.W.; Zhang, L. The Hukou System and Rural-Urban Migration in China: Processes and Changes. China Q. 1999, 160, 818-855. [CrossRef]

2. Su, Y.; Tesfazion, P.; Zhao, Z. Where are the migrants from? Inter- vs. intra-provincial rural-urban migration in China. China Econ. Rev. 2018, 47, 142-155. [CrossRef]

3. Li, H.; Lo, K.; Zhang, P. Population Shrinkage in Resource-dependent Cities in China: Processes, Patterns and Drivers. Chin. Geogr. Sci. 2019, 30, 1-15. [CrossRef]

4. Li, J.; Guo, M.; Lo, K. Estimating Housing Vacancy Rates in Rural China Using Power Consumption Data. Sustainability 2019, 11, 5722. [CrossRef]

5. Liu, Y.; Liu, Y.; Chen, Y.; Long, H. The process and driving forces of rural hollowing in China under rapid urbanization. J. Geogr. Sci. 2010, 20, 876-888. [CrossRef]

6. Ma, W.; Jiang, G.; Li, W.; Zhou, T. How do population decline, urban sprawl and industrial transformation impact land use change in rural residential areas? A comparative regional analysis at the peri-urban interface. J. Clean. Prod. 2018, 205, 76-85. [CrossRef]

7. Chunyu, M.D.; Liang, Z.; Wu, Y. Interprovincial Return Migration in China: Individual and Contextual Determinants in Sichuan Province in the 1990S. Environ. Plan A Econ. Space 2013, 45, 2939-2958. [CrossRef]

8. Zhao, Y. Causes and Consequences of Return Migration: Recent Evidence from China. J. Comp. Econ. 2002, 30, 376-394. [CrossRef]

9. Qi, W.; Deng, Y.; Fu, B. Rural attraction: The spatial pattern and driving factors of China's rural in-migration. J. Rural Stud. 2019, in press. [CrossRef]

10. Xiong, Y.; Zhang, Y.; Lee, T.J. The rural creative class: An analysis of in-migration tourism entrepreneurship. Int. J. Tour. Res. 2020, 22, 42-53. [CrossRef]

11. Song, F.; Timberlake, M. Chinese Urbanization, State Policy, and the World Economy. J. Urban. Aff. 1996, 18, 285-306. [CrossRef]

12. Chen, C.; LeGates, R.; Zhao, M.; Fang, C. The changing rural-urban divide in China's megacities. Cities 2018, 81, 81-90. [CrossRef]

13. Wu, J.; Zhuo, S.; Wu, Z. National innovation system, social entrepreneurship, and rural economic growth in China. Technol. Forecast. Soc. Chang. 2017, 121, 238-250. [CrossRef]

14. Li, A.H. E-commerce and Taobao villages. A promise for China's rural development? China Perspect. 2017, 3, 57-62. [CrossRef]

15. Lo, K.; Li, J.; Wang, M.; Li, C.; Li, S.; Li, Y. A Comparative Analysis of Participating and Non-Participating Households in Pro-Poor Tourism in Southern Shaanxi, China. Tour. Plan. Dev. 2018, 16, 318-333. [CrossRef] 
16. Wei, Y.D.; Lin, J.; Zhang, L. E-Commerce, Taobao Villages and Regional Development in China. Geogr. Rev. $2019,110,380-405$. [CrossRef]

17. Lincoln, T.; Madgin, R. The inherent malleability of heritage: Creating China's beautiful villages. Int. J. Herit. Stud. 2018, 24, 938-953. [CrossRef]

18. Yan, S.; Chen, C. The Spatial Transformation of Traditional Rural Villages Driven by Private Investment in China's Developed Areas: The Case of Daxi Village, Anji County. J. Reg. City Plan. 2018, 29, 156. [CrossRef]

19. Alba, R.; Nee, V. Rethinking assimilation theory for a new era of immigration. Int. Migr. Rev. 1997, 31, 826-874. [CrossRef] [PubMed]

20. Coulter, R.; Ham, M.v.; Findlay, A.M. Re-thinking residential mobility: Linking lives through time and space. Prog. Hum. Geogr. 2016, 40, 352-374. [CrossRef]

21. Coulter, R.; Scott, J. What Motivates Residential Mobility? Re-examining Self-Reported Reasons for Desiring and Making Residential Moves. Popul. Space Place 2015, 21, 354-371. [CrossRef]

22. Gordon, I. Migration in a Segmented Labour Market. Trans. Inst. Br. Geogr. 1995, 20, 139. [CrossRef] [PubMed]

23. Strassmann, W.P. Residential Mobility: Contrasting Approaches in Europe and the United States. Hous. Stud. 2001, 16, 7-20. [CrossRef]

24. Goetz, E.G. Forced Relocation vs. Voluntary Mobility: The Effects of Dispersal Programmes on Households. Hous. Stud. 2002, 17, 107-123. [CrossRef]

25. Lo, K.; Xue, L.; Wang, M. Spatial restructuring through poverty alleviation resettlement in rural China. J. Rural Stud. 2016, 47, 496-505. [CrossRef]

26. Lockwood, V.S. Development and return migration to rural French Polynesia. Int. Migr. Rev. 1990, 24, 347-371. [CrossRef] [PubMed]

27. Williamson, J.G. Migration and Urbanization. Handbook of Development Economics; Elsevier: Amsterdam, The Netherlands, 1988; Volume 1, pp. 425-465.

28. Cui, C.; Geertman, S.; Hooimeijer, P. Residential Mobility of Skilled Migrants in Nanjing, China. Environ. Plan. A Econ. Space 2015, 47, 625-642. [CrossRef]

29. Li, S.-M.; Mao, S. Exploring residential mobility in Chinese cities: An empirical analysis of Guangzhou. Urban Stud. 2016, 54, 3718-3737. [CrossRef]

30. Qian, J.; Zhu, H. Chinese urban migrants' sense of place: Emotional attachment, identity formation, and place dependence in the city and community of Guangzhou. Asia Pac. Viewp. 2014, 55, 81-101. [CrossRef]

31. Wu, W. Migrant Intra-urban Residential Mobility in Urban China. Hous. Stud. 2006, 21, 745-765. [CrossRef]

32. Cai, F. Spatial patterns of migration under China's reform period. Asian Pac. Migr. J. 1999, 8, 313-327. [CrossRef] [PubMed]

33. Liang, Z.; Chen, Y.P.; Gu, Y. Rural Industrialisation and Internal Migration in China. Urban Stud. 2002, 39, 2175-2187. [CrossRef]

34. Liu, T.; Qi, Y.; Cao, G.; Liu, H. Spatial patterns, driving forces, and urbanization effects of China's internal migration: County-level analysis based on the 2000 and 2010 censuses. J. Geogr. Sci. 2015, 25, 236-256. [CrossRef]

35. Wang, Y.; Liu, Y.; Li, Y.; Li, T. The spatio-temporal patterns of urban-rural development transformation in China since 1990. Habitat Int. 2016, 53, 178-187. [CrossRef]

36. Chung, H. Rural migrants in villages-in-the-city in Guangzhou, China: Multi-positionality and negotiated living strategies. Urban Stud. 2018, 55, 2245-2260. [CrossRef]

37. Wang, W.W.; Fan, C.C. Migrant Workers' Integration in Urban China: Experiences in Employment, Social Adaptation, and Self-Identity. Eurasian Geogr. Econ. 2012, 53, 731-749. [CrossRef]

38. Wang, Y.P.; Wang, Y.; Wu, J. Housing migrant workers in rapidly urbanizing regions: A study of the Chinese model in Shenzhen. Hous. Stud. 2010, 25, 83-100. [CrossRef]

39. Wu, F.; Logan, J. Do rural migrants 'float' in urban China? Neighbouring and neighbourhood sentiment in Beijing. Urban Stud. 2016, 53, 2973-2990. [CrossRef]

40. Chang, H.; Dong, X.-Y.; MacPhail, F. Labor Migration and Time Use Patterns of the Left-behind Children and Elderly in Rural China. World Dev. 2011, 39, 2199-2210. [CrossRef]

41. Jingzhong, Y.; Lu, P. Differentiated childhoods: Impacts of rural labor migration on left-behind children in China. J. Peasant Stud. 2011, 38, 355-377. [CrossRef]

42. Yeung, W.-J.J.; Gu, X. Left Behind by Parents in China: Internal Migration and Adolescents' Well-Being. Marriage Fam. Rev. 2016, 52, 127-161. [CrossRef]

43. Zhu, N.; Luo, X. The impact of migration on rural poverty and inequality: A case study in China. Agric. Econ. 2010, 41, 191-204. [CrossRef]

44. Tao, R.; Xu, Z. Urbanization, rural land system and social security for migrants in China. J. Dev. Stud. 2007, 43, 1301-1320. [CrossRef]

45. Adjei, P.O.-W.; Serbeh, R.; Adjei, J.O. Internal Migration, Poverty Reduction and Livelihood Sustainability: Differential Impact of Rural and Urban Destinations. Glob. Soc. Welf. 2017, 4, 167-177. [CrossRef]

46. Argent, N.; Tonts, M.; Jones, R.; Holmes, J. The Amenity Principle, Internal Migration, and Rural Development in Australia. Ann. Assoc. Am. Geogr. 2014, 104, 305-318. [CrossRef] 
47. Dodd, W.; Humphries, S.; Patel, K.; Majowicz, S.; Dewey, C. The internal migration-development nexus: Evidence from southern India. Asian Pac. Migr. J. 2017, 26, 56-83. [CrossRef]

48. Wang, F.; Fan, W.; Lin, X.; Liu, J.; Ye, X. Does Population Mobility Contribute to Urbanization Convergence? Empirical Evidence from Three Major Urban Agglomerations in China. Sustainability 2020, 12, 458. [CrossRef] 